International Journal of Instruction e-ISSN: 1308-1470 • www.e-iji.net
April 2019 • Vol.12, No.2

p-ISSN: 1694-609X

pp. 605-622

Received: 15/08/2018

Revision: 16/02/2019

Accepted: 23/02/2019

OnlineFirst:17/03/2019

\title{
A Study on the Assessment Methods and Experiences of Teachers at an Ethiopian University
}

\section{Abatihun A. Sewagegn}

Ph.D, Faculty of Education, University of Johannesburg, South Africa, abatihuns@uj.ac.za\&abatihunalehegn@gmail.com

Assessment plays a significant role in determining the quality of education. This is particularly so when students are properly assessed using various appropriate methods of assessment. This study investigates teachers' assessment methods and the challenges they encounter in assessing learning in an Ethiopian university. A convergent parallel mixed-method research design was used. A total of 166 from 210 sample teachers completed and returned the questionnaire. Moreover, six heads of departments and six teachers were selected for the interview. The results indicate that teachers largely depend on written assessment methods against innovative/alternative methods that would have been used to uncover students' creative and proficiency in their study areas. However, teachers encounter challenges as they attempt unfamiliar (but innovative) assessment methods. The study reveals that making the students creative and proficient in their study areas is simply untenable if teachers continue to utilise current assessment practices. This study acknowledges the contribution of effective assessment to making the students proficient in their study area. Implications of the current assessment practices are discussed and consequently, recommendations for the enactment of innovative/alternative methods are made.

Keywords: assessment, assessment methods, challenges in assessment, teachers, quality

\section{INTRODUCTION}

There have been growing concerns with improving assessment practices in higher education across the world, considering the fact that appropriate assessment methods play a vital role in achieving the goal of education in any county. Studies on classroom assessment have come to be an essential aspect of effective teaching and learning (McMillan, Myran \& Workman, 2002; Bloxham \& Boyd, 2007). Assessment has a variety of meanings within the context of higher education. It is the systematic collection and analysis of information to improve student learning and it can facilitate improvement through a variety of avenues (Stassen, 2001). Miller, Linn \& Gronlund

Citation: Sewagegn, A. A. (2019). A Study on the Assessment Methods and Experiences of Teachers at an Ethiopian University. International Journal of Instruction, 12(2), 605-622. https://doi.org/10.29333/iji.2019.12238a 
(2009) also define it as an integrated process for determining the nature and extent of student learning and development.

Assessment in higher education serves multiple purposes, such as providing information about student learning, progress, teaching quality, and ensuring the accountability of programmes and institutions (Fletcher, Meyer, Anderson, Johnston \& Rees, 2012). As Nenty, Adedoyin, Odili \& Major (2007) explain, education should have a positive impact on the behaviour of learners, and the quantity and quality of this impact can only be determined by the assessment practices in use. The most important aspects of this impact are the amount, type and level of the cognitive, affective and psychomotor skills that are developed in learners.

Ellington (2000) presents seven golden rules to become an excellent tertiary-level teacher. One of these rules refers to the appropriate use of assessment methods. As to Linn and Miller (2005), an assessment method refers to any of a variety of procedures used to obtain information about student performance. Smimou and Dahl (2012) also states that methods of assessment are teaching practices used to judge how well a student has performed in class, based on various measures as determined by the teacher or the educational system.

Alquraan (2012) emphasizes that, since well-developed assessment methods have a more positive impact on students' achievement, higher education institutions are constantly encouraged to use effective assessment methods that enhance the learning process. There are many different assessment methods used in tertiary education. When deciding which assessment method to use, both the learning outcomes and activities need to be considered so that appropriate assessment methods are aligned and used. No single assessment method is able to completely address the learning progress or achievement of students, using multiple assessments give students many opportunities to show what they know (Brookhart \& Nitko, 2008).

One of the Ethiopian government's millennium education goals involves the demand for cultivating critical-thinking, problem-solving, and higher-order-thinking skills necessary for adaptation and contribution to the rapidly changing information age. Given the current human resource demands for development in society, some cognitive skills are more desirable than others. To supply the skills demanded by society, tertiary education must lay a foundation that will ensure the development of such desirable skills among students. The assessment practices of teachers, as implemented in higher education institutions, have a vital contribution to make in this regard. However, the current trends in Ethiopia show that assessment is not handled properly or in accordance with actual requirements to make the students creative and proficient in learning as to the researcher observation. All teachers must have assessment skills in order to successfully implement assessments. Teachers use various techniques in assessment, even though they may not have received appropriate training on certain aspects of classroom assessment (Marso \& Pigge as cited in Tadesse, 2009). As such, studies show that most teachers lack effective assessment knowledge and skills in their evaluation of academic achievement to make proficient their students (McMillan, 2001; Adedoyin, 2012). 
Currently, not much is known about Ethiopian higher institution teachers' use of student assessment and the problem they experience. Therefore, the main aim of the study is to investigate the assessment methods that the teachers are using and the problems/challenges that teachers experience in the assessment of students learning at a university in Ethiopia. The study specifically raises the following research questions:

i. Which assessment methods are predominantly used by teachers?

ii. What are the problems/challenges that teachers experience regarding assessment?

This study attempts to add to the existing body of knowledge regarding the good practice of assessment in making the students proficient in their study area in particular and in the real world of work in general.

\section{METHOD}

\section{Research Design}

In the study, a mixed-method approach was used. De Vos, Strydom, Fouche and Delport (2011) noted that mixed-method studies are those that combine the qualitative and quantitative approaches in a single study. According to Creswell (2012), the basic assumption of combining the two approaches is that, it provides a better understanding of the research problem and question than either method by itself.

From the six mixed-method designs identified by Creswell (2012), this study follows the convergent parallel design, because this design gives chance to collect both quantitative and qualitative data simultaneously, analyze it and is appropriate for the research question raised. The following figure gives a clear picture of the convergent parallel design used in this study.

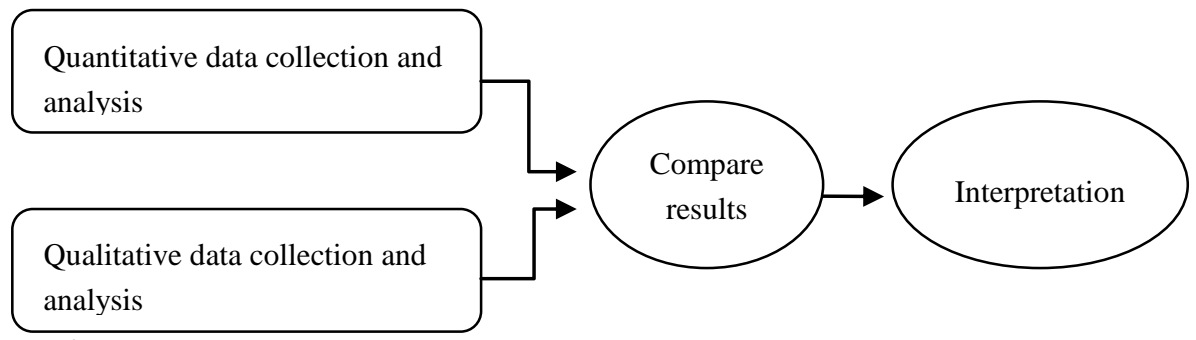

Figure 1

The Mixed-Method Design used in this Study

(Source: Creswell, 2012: 541)

The specific type of research design that is used for the quantitative phase of this study is a descriptive survey. In descriptive survey research, the researcher selects a sample of subjects and administers a questionnaire to collect data (Creswell, 2009). Therefore, descriptive survey is used to describe the practice of the respondents about the assessment methods implemented in the university. 
The research design used for the qualitative approach is Phenomenology. According to Creswell (2009), phenomenological research is a qualitative strategy in which the researcher identifies the essence of human experiences about a phenomenon as described by participants in a study. This is to get insight into the phenomenon from the participants' point of view. It is also contextual. A context represents the specific set of properties that pertain to phenomena and a contextual study tends to be descriptive and exploratory (Ibid).

\section{Participants}

The setting selected to conduct the study was a university in Ethiopia (Debre Markos University). Teachers and head of departments were the participants. All teachers who were on duty and head of departments were the target population of the study. At the university, there are six colleges (Social Science and Humanities, Natural and Computational Science, Business and Economics, Technology, Health Science, Agriculture as well as the School of Law) and different departments within each college except school of law. Stratified and simple random sampling techniques (for the quantitative part) and purposive and available sampling techniques (for the qualitative part) were used. From a total of 450 teachers, 210 teachers were selected as the sample using the above sampling techniques.

\section{Instruments}

Questionnaire: A closed and open-ended questionnaire developed by the researcher was used. The questionnaire has two sections excluding the biographic information. The first section addresses the assessment methods teachers tend to use (16 items). The different assessment methods included in the questionnaire are arranged based on the researcher experience in teaching and from difference assessment literatures (Race, Brown, and Smith, 2005; Berry, 2008). Each item of the questionnaire has five options, which aimed to determine the degree to which the listed assessment methods are being used. The options are coded and scored as follows: $1=$ never, $2=$ rarely, $3=$ sometimes, $4=$ frequently, and $5=$ always. In addition, for this part there is a blank space for respondents to list other assessment methods they use.

The second section is the possible problems/challenges teachers experience regarding assessment (10 items). For each item, there are five options, which is coded and scored as follows: $1=$ strongly disagree, $2=$ disagree, $3=$ undecided, $4=$ agree and $5=$ strongly agree. In addition, a blank space is provided to list other problems if they experience not to implement assessment properly.

Interview: Two versions of semi-structured interview schedules were developed by the researcher and conducted with head of department and teachers. Six department heads, one from each college, were purposively selected and six teachers', one from each college, were selected using available sampling methods. Since the head of departments are small in number and closely follow the assessment and instructional activity of teachers, interviewing them is better to get detail information. The interview is used to identify the different assessment methods used by teachers and the problems they experience regarding assessment. 


\section{Procedure of Data Collection}

The quantitative and qualitative data are collected simultaneously after refining the instrument via pilot study. The quantitative data using questionnaire was collected from teachers after obtaining permission from the university and consent from the teachers and head of departments to complete it and for the interview. After the necessary data are collected, the analysis has been conducted considering the nature of the data.

\section{Data Analysis}

The data collected through questionnaires were coded, entered, cleaned and analyzed using SPSS version 20. To analyze the quantitative data, simple percentages, mean and Chi-square $\left(x^{2}\right)$ statistics were used. Chi-square test was used to check whether there is a significant difference between the rating patterns of responses. The Alpha $(\alpha)$ value for test of significance is set at 0.05 . The qualitative data obtained through open-ended questions and interviews were analyzed and interpreted thematically. Analysis of quantitative data are displayed first and then corroborated by qualitative data analysis in the form of texts.

\section{Validity and Reliability}

A pilot study was conducted with a total of 18 teachers to ensure reliability and validity of the instruments used. To increase the validity of the questionnaires and interview items, four selected experts in the area were involved to review the items for clarity and relevance. The reliability of the pilot and main questionnaires was checked using Cronbach's Alpha. This method of estimating reliability was used when the items are not scored dichotomously (Mehrens \& Lehmann, 1991). The acceptable range of reliability coefficients for most instruments is 0.70 to 1.00 . Table 1 below shows the summary of the reliability of the pilot and main data of the teachers' questionnaire.

Table 1

Reliability of the Pilot and Main Data

\begin{tabular}{lll}
\hline \multirow{2}{*}{ Parts of the questionnaire } & $\begin{array}{l}\text { Pilot study } \\
\text { reliability }\end{array}$ & $\begin{array}{l}\text { Main study } \\
\text { reliability }\end{array}$ \\
\hline \multirow{2}{*}{ Part I: Assessment methods predominantly used } & 0.546 & 0.738 \\
Part II: Problems instructors experience & 16 items & 0.733 \\
& 10 items & 0.770 \\
& regarding assessment & 10 items \\
\hline
\end{tabular}

George and Mallery (2003) provide a standard to interpret the reliability of instruments. The standard to interpret Cronbach's Alpha reliability co-efficient is that if it is greater than 0.90 (excellent), from 0.80 to 0.89 (good), from 0.70 to 0.79 (acceptable), from 0.60 to 0.69 (questionable), from 0.50 to 0.59 (poor) and less than 0.50 (unacceptable)

As indicated in Table 1, the reliability of the pilot data of the teachers questionnaire are 0.546 and 0.733 for part I and II respectively. The reliability of Part I of the pilot data is poor on the basis of the standard. Therefore, for Part I corrective measures were taken. That is, after looking the items in detail and on the bases of the experts comment and 
refining it, pilot study was conducted for the second time for this part only with 12 teachers and the reliability becomes 0.71 . After refining all the items of the teacher's questionnaire on the bases of the teachers and experts comments, the reliabilities of the parts of the main data are 0.738 and 0.770 , which are within the range of acceptability

\section{FINDINGS}

The data is reported in the order of the research questions. A total of 166 from 210 teachers completed and returned the questionnaire.

\section{Assessment Methods Predominantly Used by Teachers}

Table 2

Frequency of Use of Different Assessment Methods

\begin{tabular}{|c|c|c|c|c|c|c|c|c|c|c|c|}
\hline \multirow{3}{*}{$\begin{array}{l}\text { Assessment } \\
\text { method }\end{array}$} & \multicolumn{10}{|c|}{ The degree to which the assessment method is being used } & \multirow{3}{*}{$\begin{array}{l}\text { Chi-Square } \\
(\chi 2) \text { Value }\end{array}$} \\
\hline & \multicolumn{2}{|c|}{ Always } & \multicolumn{2}{|c|}{ Frequently } & \multicolumn{2}{|c|}{ Sometimes } & \multicolumn{2}{|c|}{ Rarely } & \multicolumn{2}{|c|}{ Never } & \\
\hline & f & $\%$ & $\mathrm{f}$ & $\%$ & $\mathrm{f}$ & $\%$ & $\mathrm{f}$ & $\%$ & $\mathrm{f}$ & $\%$ & \\
\hline Quizzes & 30 & 18.1 & 67 & 40.4 & 57 & 34.3 & 10 & 6.0 & 2 & 1.2 & $97.313^{*}$ \\
\hline $\begin{array}{l}\text { Mid-semester } \\
\text { tests }\end{array}$ & 34 & 20.5 & 36 & 21.7 & 38 & 22.9 & 27 & 16.3 & 31 & 18.7 & 2.253 \\
\hline Final exam & 116 & 69.9 & 30 & 18.1 & 9 & 5.4 & 11 & 0.1 & 0 & 0 & 184.795* \\
\hline Group works & 76 & 45.8 & 62 & 37.4 & 25 & 15.1 & 3 & 1.8 & 0 & 0 & $81.084 *$ \\
\hline Presentations & 29 & 17.5 & 36 & 21.7 & 79 & 47.6 & 21 & 12.6 & 1 & 0.60 & $99.663 *$ \\
\hline $\begin{array}{l}\text { Individual } \\
\text { assignments }\end{array}$ & 27 & 16.3 & 39 & 23.5 & 72 & 43.4 & 20 & 12.1 & 8 & 4.8 & $71.892 *$ \\
\hline $\begin{array}{l}\text { Oral } \\
\text { questions }\end{array}$ & 53 & 31.93 & 28 & 16.9 & 32 & 19.3 & 36 & 21.7 & 17 & 10.2 & $20.807^{*}$ \\
\hline $\begin{array}{l}\text { Research } \\
\text { reports }\end{array}$ & 5 & 3.01 & 13 & 7.8 & 47 & 71.2 & 58 & 34.9 & 43 & 25.9 & $63.807 *$ \\
\hline Seminars & 2 & 1.20 & 11 & 6.6 & 38 & 22.9 & 51 & 30.7 & 64 & 38.6 & $82.976^{*}$ \\
\hline Project works & 6 & 3.61 & 17 & 10.2 & 75 & 45.2 & 42 & 25.3 & 26 & 0.2 & $86.711 *$ \\
\hline Performance & 12 & 7.8 & 29 & 17.5 & 53 & 31.9 & 33 & 19.9 & 39 & 23.5 & $26.892 *$ \\
\hline Portfolio & 5 & 3.0 & 10 & 6.0 & 31 & 18.7 & 35 & 21.1 & 85 & 51.2 & $121.723^{*}$ \\
\hline Observations & 16 & 9.63 & 24 & 14.5 & 47 & 28.3 & 48 & 28.9 & 41 & 24.7 & $17.723^{*}$ \\
\hline $\begin{array}{l}\text { Self- } \\
\text { assessment }\end{array}$ & 0 & 0 & 0 & 0 & 15 & 9.0 & 70 & 42.2 & 81 & 47.8 & $45.193 *$ \\
\hline $\begin{array}{l}\text { Peer } \\
\text { assessment }\end{array}$ & 0 & 0 & 1 & 0.60 & 10 & 6.02 & 61 & 36.8 & 94 & 56.6 & $139.012^{*}$ \\
\hline $\begin{array}{l}\text { Laboratory } \\
\text { works }\end{array}$ & 15 & 9.0 & 19 & 11.4 & 37 & 22.3 & 26 & 15.7 & 69 & 41.6 & $56.651 *$ \\
\hline
\end{tabular}

As indicated in Table 2 , teachers use quizzes $(40.4 \%=$ frequently), group work $(45.8 \%$ $=$ always and $37.4 \%=$ frequently $)$ and final examination $(69.9 \%=$ always $)$ most of the time. The chi-square test result showed that there is statistically significant difference on the rating pattern of responses. That is the difference was in favour of teachers those who uses quizzes, group assignments and final examination always and frequently.

Presentation (47.6\%), individual assignment (43.4\%) and project works (45.2\%) are used only sometimes. For these items the chi-square test result showed that there is statistically significant difference on the rating pattern of responses. That is the difference was in favour of those teachers who often use presentation, individual assignments and project works. 
However, most teachers never use portfolio (51.2\%), self-assessment (47.8\%), peerassessment $(56.6 \%)$, performance tests $(23.5 \%)$, seminar $(38.6 \%)$ and research reports $(25.9 \%)$. Again for these items the chi-square test result showed that there is statistically significant difference on the rating pattern of responses. The difference was in favour of those teachers who never use presentation, self-assessment, peer-assessment, seminar and research reports.

In addition, $25.3 \%, 42.2 \%, 36.8 \%$ and $34.9 \%$ of the teachers rarely use project works, self-assessment, peer assessment and research reports respectively. Though there is an attempt to use a variety of assessment methods, still most teachers depend on the usual written assessment methods.

Table 3

Assessment Methods Used by Teachers in Descending Order of the Mean

\begin{tabular}{lll}
\hline S. No. & Assessment methods/techniques & Mean \\
\hline 1 & Final examinations & 4.51 \\
\hline 2 & Group works/assignments & 4.27 \\
\hline 3 & Quizzes & 3.68 \\
\hline 4 & Presentations & 3.43 \\
\hline 5 & Oral questions & 3.39 \\
\hline 6 & Individual assignments & 3.34 \\
\hline 7 & Mid-semester tests & 3.09 \\
\hline 8 & Performance (practical) tests & 2.65 \\
\hline 9 & Observations & 2.61 \\
\hline 10 & Project works & 2.61 \\
\hline 11 & Laboratory works & 2.31 \\
\hline 12 & Research reports & 2.27 \\
\hline 13 & Seminars & 2.01 \\
\hline 14 & Portfolio & 1.89 \\
\hline 15 & Self-assessment & 1.60 \\
\hline 16 & Peer-assessment & 1.51 \\
\hline
\end{tabular}

As is shown in Table 3, from top to bottom, the mean values of the assessment methods used decreases. That means, for each of the listed assessment methods, when all teachers use the listed assessment methods, the mean value approaches five. The mean value is close to one, when most of the teachers did not use the listed assessment method. Therefore, most of the times the assessment methods listed from numbers 1 to 7 are used by the teachers. However, the assessment methods, which are listed from numbers 8 to 16 , are not commonly used by teachers, even if their competency that is, making the students creative and proficient is more than the first seven assessment methods.

In addition to the information obtained using questionnaire, the interview which was conducted with teachers and department heads regarding the commonly used assessment methods yielded the following results. Most of the data obtained from the interview is similar to the information obtained through the questionnaire. A teacher who participated in an interview responded that "the assessment methods that I have used commonly are paper and pencil tests, group and individual assignments" [Teacher B]. 
In general, teachers from other participant colleges use pencil-and-paper tests, group assignments and presentations, and oral questions during the class hour. They did not use other methods to help students to be creative and proficient in their study area.

Head of departments from different colleges shared the teachers' ideas as presented above. These participants confirmed that teachers used quizzes, tests, exams, group assignments (commonly), individual assignments (rarely), and presentation (rarely). For example, one participant from the College of Business and Economics noted that:

My department teachers follow the usual assessment method which is practiced in the university. For example, they use quizzes, tests, assignments, final exam etc. They didn't apply other different assessment method which helps students to be creative and proficient other than these. [Head of E]

\section{Problems Instructors Experience Regarding Assessment}

Table 4

Frequency of the Factors Instructors Experience Regarding Assessment

\begin{tabular}{|c|c|c|c|c|c|c|c|c|c|c|c|}
\hline \multirow{3}{*}{ Factors/problems } & \multicolumn{10}{|c|}{ Level of agreement } & \multirow{3}{*}{ 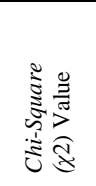 } \\
\hline & \multicolumn{2}{|c|}{$\begin{array}{l}\text { Strongly } \\
\text { Agree }\end{array}$} & \multicolumn{2}{|c|}{ Agree } & \multicolumn{2}{|c|}{ Undecided } & \multicolumn{2}{|c|}{ Disagree } & \multicolumn{2}{|c|}{$\begin{array}{l}\text { Strongly } \\
\text { disagree }\end{array}$} & \\
\hline & $\mathrm{f}$ & $\%$ & $\mathrm{f}$ & $\%$ & $f$ & $\%$ & $\mathrm{~F}$ & $\%$ & $f$ & $\%$ & \\
\hline $\begin{array}{l}\text { Large number of } \\
\text { students in the class }\end{array}$ & 111 & 66.8 & 42 & 25.3 & 7 & 4.2 & 3 & 1.8 & 3 & 1.8 & $260.265^{*}$ \\
\hline $\begin{array}{l}\text { Lack of awareness } \\
\text { on different } \\
\text { assessment methods }\end{array}$ & 10 & 6.0 & 63 & 38.0 & 20 & 12.1 & 56 & 33.7 & 17 & 10.2 & $71.771^{*}$ \\
\hline $\begin{array}{l}\text { Lack of training on } \\
\text { the application of } \\
\text { different assessment } \\
\text { methods }\end{array}$ & 16 & 9.6 & 55 & 33.1 & 22 & 13.3 & 57 & 34.3 & 16 & 9.6 & $52.976^{*}$ \\
\hline Shortage of time & 61 & 36.8 & 75 & 45.2 & 17 & 10.2 & 9 & 5.4 & 4 & 2.4 & 127.133* \\
\hline High workload & 52 & 31.3 & 52 & 31.3 & 24 & 14.5 & 34 & 20.5 & 4 & 2.4 & $49.542 *$ \\
\hline $\begin{array}{l}\text { Students' low } \\
\text { achievement level }\end{array}$ & 49 & 29.5 & 58 & 34.9 & 26 & 15.7 & 26 & 15.7 & 7 & 4.22 & $49.843^{*}$ \\
\hline $\begin{array}{l}\text { Insufficient } \\
\text { experience in } \\
\text { teaching }\end{array}$ & 13 & 7.8 & 40 & 24.1 & 27 & 16.3 & 57 & 34.3 & 29 & 17.5 & $32.434 *$ \\
\hline $\begin{array}{l}\text { Insufficient } \\
\text { resources }\end{array}$ & 54 & 32.5 & 74 & 44.6 & 13 & 7.8 & 21 & 12.7 & 4 & 2.4 & $105.627^{*}$ \\
\hline $\begin{array}{l}\text { Negative belief } \\
\text { about the use of } \\
\text { different assessment }\end{array}$ & 19 & 11.5 & 26 & 15.7 & 30 & 18.1 & 56 & 33.7 & 35 & 21.1 & $23.699 *$ \\
\hline $\begin{array}{l}\text { Lack of commitment } \\
\text { to use different } \\
\text { assessment methods }\end{array}$ & 9 & 5.4 & 53 & 31.9 & 22 & 13.2 & 55 & 33.1 & 27 & 16.3 & $48.699 *$ \\
\hline
\end{tabular}

As can be seen in Table 4, large number of students in one class is the major problem teachers' face to use different assessment methods as $66.9 \%$ and $25.3 \%$ of the respondents tend to agree. Lack of awareness and lack of training on different assessment methods are also the problems teachers even if $33.7 \%$ and $34.3 \%$ of the respondents disagreed as these are not the problems. Moreover, shortage of time, high workload, students' low achievement level, and insufficient resources are the major 
problems teachers experience as $36.8 \%, 31.3 \%, 29.5 \%$, and $32.5 \%$ of the respondents strongly agreed and $45.2 \%, 31.3 \%, 34.9 \%$ and $44.6 \%$ of the respondents agreed respectively. The chi-square test result showed that there is statistically significant difference on the rating pattern of responses. The difference was in favour of teachers those who agree and strongly agree on the issue. This means that all these are the major problems that teachers face not to make the students creative and proficient in their study area.

Table 5

Problems Teachers Experience Regarding Assessment in Descending Order of the Mean

\begin{tabular}{lll}
\hline S. No. & Factors/problems & Mean \\
\hline 1 & Large number of students in the class & 4.54 \\
\hline 2 & Shortage of time & 4.08 \\
\hline 3 & Insufficient resources & 3.92 \\
\hline 4 & Students' low achievement level & 3.70 \\
\hline 5 & High workload & 3.69 \\
\hline 6 & Lack of training on the application of different assessment methods & 2.99 \\
\hline 7 & Lack of awareness on different assessment methods & 2.96 \\
\hline 8 & Lack of commitment to use different assessment methods & 2.77 \\
\hline 9 & Insufficient experience in teaching & 2.70 \\
\hline 10 & Negative belief about the use of different assessment techniques & 2.63 \\
\hline
\end{tabular}

In order to see the problems that teachers experience when using different assessment methods, the mean scores are arranged in descending order, as is indicated in the above table. That is the maximum mean is 5 , which means strongly agree and the minimum mean score is 1 , which is strongly disagree. Therefore, the mean values of those teachers who choose large number of students in one class as a major problem are 4.62 which is the highest mean score. In addition, shortage of time, insufficient resources, students' low achievement level and high workload are also the problems that affect teachers not to implement the assessment properly. However, the last category of the problems is not considered as a major factor teacher's face when assessing students.

In addition to the above quantitative information regarding the problems that teachers face in the assessment of students' learning, the qualitative data yields the following information.

Large number of students in one class: Most of the teacher participants interviewed view this as a major challenge in the assessment of their students' learning. For example, a teacher from one college had the following to say on the matter:

Large class size is the major problem to evaluate the performance of individual students. For example, if the number of students is more than 40 , it is difficult to evaluate students individually because there may be shortage of time to give feedback for each of them. Therefore, the large number of students in one class has its own negative impact in the proper implementation of different assessment methods. [Teacher P] 
Department heads in different colleges share the above idea. For example, a participant from the college of business and economics supports this argument as follows:

Yes, the basic problem in our college in particular and in the university in general is large number of students in one class. It is very difficult to manage and assess the performance of each and every student. The number is above the standard. It is about 60 and 65 student on average in one class. We sought a solution for this problem. We asked the university management body in different meeting, but there is no reasonable response. So, we are living with the problem. [Head of ED]

Shortage of time: Having enough time is very important in the assessment of the students" learning. A respondent said that, "if the number of students is large, it is difficult to assess and give timely feedback for every individual student with the given time" [Teacher $\mathrm{H}]$.

High workload: If a teachers has extra work and is over loaded, it affects his/her practice of assessment. One of the participants' described this problem as follows: "Due to the workload, I couldn't give frequent and immediate feedback to my students" [Teacher H]. Another participant teacher added that, "due to large number of students in one class and workload on teachers, it is difficult to effectively evaluate each student" [Teacher B].

Insufficient resources: A teacher responded that:

There is shortage of equipment to show practical issues and to support the theoretical concept. In addition, the classrooms are not clean and there are broken chairs in the room. The chairs are not sufficient and the students waste their time in pulling the chairs here and there. [Teacher $\mathrm{H}$ ]

Another teacher from another college said that "shortages of material like paper and organized laboratory equipment is a problem in our department" [Teacher M]. Therefore, this limits teachers from making the students creative and efficient. In relation to this, one of my interviewees noted that "the shortage of laboratory materials limits teachers not to use different assessment methods" [Head of CoTM].

Students' low achievement level: As most teachers explained weak academic background of students as a means to achieving low grades/results and this creates a big problem in the assessment of students' learning. As one of my participant puts it:

Weak academic background of students influences my practice of assessment. Most of the students joined different departments not on the bases of their interest. When we see most students who are in my department (i.e. Biology) they joined it to escape from the challenging courses like mathematics, physics and chemistry as biology department has no advanced mathematical courses relatively the limited language skill of the students is another problem. For example, you may write a question in a good way but the students may not understand it easily and they may not write anything on the answer sheet or the space provided. [Teacher B] 
As a result of their weak academic background, students those are academically weak depend on capable students. A teacher had the following to say:

Dependency in group works is the main problem in my current practice of assessment. That means the assignment is done by one or two students only. The other members of the group contribute nothing in the group task. They simply write their name and ID number and put their signature on it. So, with this problem it is very difficult to make the students creative and proficient. [Instructor P]

Lack of training and awareness on the application of different assessment methods: Teacher's lack of pedagogical training and awareness on the use of different assessment methods is the problem in the assessment of students' learning as most of the participants responded. In relation to this, one of my participants' noted that, "since our department teachers have no pedagogical background, they face problem in the use of different assessment methods" [Head of CoTM].

Lack of commitment and negative beliefs about the use of different assessment methods: If there is lack of commitment from the side of teachers to use different assessment methods properly and from the side of the students to be assessed with different assessment methods, it is difficult to make them creative and proficient. A teacher reflected as follows:

There is a problem of commitment from both parties: from teachers and from students. Students are not interested to do assignments or group tasks effectively. They want to get good mark and pass exams easily. Teachers in their part, assess students with tests and exams only. But using one or two assessment methods does not show the students real performance. [Teacher PH]

Regarding this, a head of department from the Technology College noted that:

Some teachers do not give feedback for students at all even if the students' number in one class is large. In think this is their carelessness. Even in the exam room, they do not invigilate students properly; instead they open way for cheating. If a teacher do not show the students result on time, he/she cannot be ready for the next. [Head of CoTM]

Most of the participants responded that cheating is a major problem in their department. For example, one of the participants' revealed the following:

Cheating is a factor which affects the assessment of students' learning. That means, if a student obtains good score by cheating, the result that the student obtains does not reflect his/her real performance. [Instructor P].

\section{DISCUSSION}

This study has attempted to investigate the assessment methods that the teachers are using and identify the problems that teachers experience in the assessment of students learning at a university in Ethiopia. 


\section{Predominantly Used Assessment Methods}

According to Chan (2007), no single assessment is able to address the learning progress or achievement of students completely. Brookhart and Nitko (2008) add that using multiple assessments gives students many opportunities to show what they know.

However, teachers of the selected institution are not using a variety of assessment methods and prefer pencil-and-paper tests. But, using pencil-and-paper assessment methods is not enough to see the competency and performance of a student because of the weakness they have. For example, Luyegu (2009) notes that test scores cannot tell about the academic development of learners. Similarly, they cannot tell what a particular difficulty the students had during a test. From the descriptive data (on Table 3 and 4) indicates that most of the teachers are very much dependent on the usual written/traditional assessment methods. The interview result also indicates that most teachers use pencil-and-paper tests and group assignments. Pencil-and-paper tests are traditional assessments (Dikli, 2003; Luyegu, 2009; Dogan, 2011). Frank and Barzilai (2004) also remark that traditional assessment in most courses of the higher education is mainly based on pencil-and-paper tests. Even if the traditional forms of assessment are time and cost effective and the measurement is consistent, they have been criticized for promoting a surface approach to learning (Luyegu, 2009).

On the other hand, Dogan (2011) notes that, in order to enhance the proficiency of students, alternative assessment methods should be used to assess the knowledge and skills of students that are not well captured by traditional assessment methods. Alternative assessment may include peer assessment, debates, observation, group work, student self-assessment, project or seminar works and presentations, portfolios, the use of technology in the assessment process, or the assessment of multiple drafts of written work or projects (Dikli, 2003; Dogan, 2011).

However, the result of the present study indicated that alternative assessments (selfassessment, peer assessment, portfolio, seminars, project works and others) are not commonly used by teachers in the selected institution (see Table 4). However, if the teachers use different alternative assessment methods there is a tendency to enhance the competency of students in their learning. According to Dogan (2011), the general purposes of alternative assessments are to motivate students to do their best work, build the self-confidence of students, show improvement in students' work over time, and show the best work of students in a specific area.

\section{Problems Teachers Experience Regarding Assessment}

To assess students effectively, teachers are influenced by different factors. Knowing the factors or problems is important in order to find possible solution. Duncan and Noonan (2007) note that it is important to know how teachers' assessment strategies and grading practices are influenced by the type of classroom learning conditions like class size, teachers training, teaching experience and others. In the present study, the factors that limit teachers in assessment of students' learning are related to the teachers themselves, the students, resources and others. A study by Chan (2007) at school level identified different areas contributing to the non-use of multiple assessment methods. The result of 
the quantitative data showed that large number of students in one class, shortage of time, insufficient resources, students low achievement level and high workload on teachers are the major problems that teachers face in assessment of students' learning (see Table 5 and 6). Below is the detailed discussion of the problems that the teachers face in the assessment process.

Large number of students in one class: It is the major challenge in the assessment of students' learning. From the total of 166 respondents, $111(66.87 \%)$ and $42(25.30 \%)$ of the teachers strongly agreed and agreed that large number of students in one class is the major challenge in the assessment of students' learning. Interviewees' revealed that large number of students in each class makes it difficult to evaluate the performance of individual students. Providing timely feedback is also problematic for this reason. Therefore, the teachers are forced to use limited traditional assessment methods. Messineo, Gaither, Bott \& Ritchey (2007) support the above finding. According to these authors, the sheer number of students in overcrowded classes limits the teacher's ability to implement discussion, timely feedback, and active problem solving.

Jones (2006) and Finn, Gerber and Boyd-Zaharias (2003, in Masole \& Howie, 2013) argue that, for effective instructional delivery and high achievement, class size should not exceed 25 students. However, in most Ethiopian universities, the number of students in one class is unmanageable. The majority of interviewees noted that "currently the average number of students in one class is 60 and above". So how can a teacher manage and assess such a large number of students? According to Adula (2008), in order to apply active learning in teaching, the number of students in a given class should be reasonable so that teachers could be able to assess individual students, use multiple assessment techniques, give feedback to students on time and give equal chance to all students.

Shortage of time and heavy teacher workload: These two elements negatively affect the assessment practices of teachers in the selected institution. Norton, Norton, \& Sadler (2012) argue that lecturers feel that one of the barriers to good assessment and feedback practice is time limitation and workload. Moreover, lack of time due to workload prevents the lecturer from giving good quality feedback. The interview data also indicated that shortage of time and heavy teacher workload limits them not to properly assess the students' learning. In relation to this, Beyene and Wolde-Mariam (2014) has found that workload is an obstacle to improved implementation of active learning and assessment. From this one can understand that number of students in one class, time availability and the workload are interconnected. In addition, Oladele's (2011) study found that, as lecturers hold more administrative positions, the use of authentic assessments decreased.

Insufficient resources: For effective teaching, learning and assessment, the availability of resources is vital. As most respondents agreed, shortage of resources is the challenge that teachers face in the assessment of students' learning. On the bases of interview data shortage of relevant reference materials for library works and home based activities, shortage/inaccessibility of chemicals and instruments for laboratory courses, lack of 
educational facilities like copier, printer and shortage of computer lab are the challenges that most teachers face.

Lack of commitment and negative beliefs about the use of different assessment methods: Teachers' lack of commitment to assess students' learning with different assessment methods and their negative beliefs about alternative assessment methods are obstacles to make students creative and efficient in their study areas. The quality of learning can be adversely affected when beliefs about assessment are particularly negative. The quantitative analysis indicated that $27.11 \%$ of the respondents have negative beliefs about the use of different assessment methods and $47.15 \%$ are not committed to use different assessment methods. From this, it is possible to argue that there are problems in commitment and negative beliefs about using different assessment methods. Samuelowicz and Bain (2002) strengthen the above idea that the particular beliefs held by university teachers and students about assessment have a significant impact on teaching and learning practices.

The interview data also indicated that there are problems of commitment from both parties (teachers and students). That is, heads of department mentioned that some teachers do not give feedback to their students. This indicates that they have no commitment. In addition, in the exam room they could not invigilate students properly; instead they open way for cheating and they do not show their result on time. Therefore, this is an obstacle for the students not to be ready for the next task.

Students low achievement level: According to Nega (2012), many students join Ethiopian universities without an adequate academic background. If students have weak academic background, they may not be actively engaged in the assessment tasks. The result of the present study shows, low achievement level of students is the major problem.

Teacher interviewees explained that weak academic background is the reason for underachieving students. Mostly, academically weak students depend on capable students in group assignments and in any group tasks. As the interviewees described group assignments are done by one or two students only, the other members of the group contribute nothing in the group task. Chang and Kang (2016) finding showed that one group member may sometimes take the responsibility of doing the bulk of the work, which means the other members are dependent on him/her.

All the above problems influence teachers negatively in making the students creative and proficient through their assessment practices. These findings show that teachers' assessment practices at the university is affected by a multitude of complex problems. One may imagine how these problems in the assessment practices affect quality of student learning in the university.

\section{CONCLUSION}

This study focused on investigating the assessment methods that the teachers are using and the problems/challenges that teachers experience in the assessment of students. Based on the findings the following conclusions are drawn. 
To make the students competent in their field of study, using only traditional assessment methods is not enough. Traditional assessment methods on their own are not sufficient to enhance the competency of the students' learning ability. Therefore, the use of various alternative assessment methods is crucial to enabling students to be more creative, proficient and productive in their study areas.

In the assessment of students' learning, teachers face different problems, such as large student numbers per class, insufficient time to assess so many students individually, insufficient resources, and, consequently, very large workloads. At the same time, teachers' failed to provide appropriate and timely feedback to students, lacked awareness of and training on the application of different assessment methods, lacked commitment, and held negative beliefs about the use of different assessment methods. Meanwhile, students' low achievement levels, overdependence, and lack of involvement in, or commitment to do, the given tasks properly also affected the quality of their learning assessments. In general, all of these problems hindered the creativity and proficiency of students in their learning because the quality of assessment was directly linked to the different quality-related aspects of education, like manageable class sizes, adequate resources, relevant and sufficient teacher training, adequate and appropriate teacher experience, and satisfactory instructor education levels. Ultimately, evidence of student competency through teachers' assessment practice in the selected institution was not encouraging because they said assessment practices were overly traditional and theoretical. Using only these assessment methods, teachers cannot help their students to become more creative and proficient because no clear indication of their different skills or abilities can be obtained by these means.

\section{RECOMMENDATIONS}

Based on the findings, the following recommendations are offered to rectify the situation and facilitate the competency of students through assessment practices:

- The assessment practices that are implemented in higher education institutions should be in line with the real world of work; that is, they should consider reallife situations and it should be practical and appropriate feedback should be given for every assessment.

- Teachers should be committed to using various assessment methods, which help students to be creative, effective and knowledgeable.

- With regard to the problems posed such as large classes and inadequate resources, the university and the Ministry of Education should seek immediate solutions.

- Further research, covering more government and privately owned universities, should be conducted to substantiate the findings of the current study and strengthen its contribution towards the development of sound research data. 


\section{REFERENCES}

Adedoyin, O. O. (2012). Teachers' self-perceived professional development needs regarding classroom assessment skills. International Journal of Asian Science, 2(1), 1421.

Adula, B. (2008). Application of higher diploma program training skills in classroom instruction: the case of education faculty, Jimma University (Ethiopia). Ethiopian Journal Education and Sciences, 4(1), 51-72.

Alquraan, M. F. (2012). Methods of assessing students' learning in higher education. Education, Business and Society: Contemporary Middle Eastern Issues, 5(2), 124-133.

Berry, R. (2008). Assessment for learning. Hong Kong, Hong Kong University Press.

Beyene, Y. S., \& Wolde-Mariam, G. S. (2014). The implementation of continuous assessment in writing classes of Jimma College of teachers education. Ethiopian Journal of Education and Sciences, 10(1), 109-235.

Bloxham, S., \& Boyd, P. (2007). Developing effective assessment in higher educationa practical guide. New York: Open University press.

Brookhart, S. M., \& Nitko, A. J. (2008). Assessment and grading in classrooms. Upper Saddle River, NJ: Pearson Prentice Hall.

Chan, Y. C. (2007). Elementary school EFL teachers' beliefs and practices of multiple assessments in the northern Taiwan. Reflections on English Language Teaching, 7(1), 37-62.

Chang, B., \& Kang, H. (2016). Challenges facing group work online. Distance education, 37(1), 73-88.

Cohen, L., Manion, L., \& Morrison, K. (2011). Research methods in education. $7^{\text {th }}$ ed. New York, NY: Routledge.

Creswell, J. W. (2009). Research Design: Qualitative, Quantitative, and Mixed Method Approaches. 3rd ed. Thousand Oaks, CA: SAGE.

Creswell, J. W. (2012). Educational research: planning, conducting, and evaluating quantitative and qualitative research. 4th ed. Boston, MA: Pearson.

De Vos, A. S., Strydom, H., Fouche, C. B., \& Delport, C. S. L. (2011). Research at grass roots. For the social sciences and human service professions. 4th ed. Pretoria: Van Schaik.

Dikli, S. (2003). Assessment at a distance: traditional vs. alternative assessments. The Turkish Online Journal of Educational Technology, 2(2), 13-19.

Dogan, M. (2011). Student teachers' views about assessment and evaluation methods in mathematics. Educational Research and Reviews, 6(5), 417-431. 
Duncan, C. R. \& Noonan, B. (2007). 'Factors Affecting teachers' grading and assessment practices'. The Alberta Journal of Educational Research, 53(1), 1-21.

Ellington, H. (2000). How to become an excellent tertiary-level teacher: seven golden rules for university and college lecturers. Journal of Further and Higher Education, 24(3), 311-321.

Fletcher, R. B., Meyer L. H., Anderson, H., Johnston, P., \& Rees, M. (2012). Faculty and students conceptions of assessment in higher education. Journal of Higher Education, 64(1), 119-133.

Frank, M., \& Barzilai, A. (2004). Integrating alternative assessment in a project-based learning course for pre-service science and technology teachers. Assessment \& Evaluation in Higher Education, 29(1), 41-61.

George, D., \& Mallery, P. (2003). SPSS for windows step by step: A simple guide and reference 11.0 Update. 4th ed. Boston, MA: Allyn \& Bacon.

Linn, R., \& Miller, M. (2005). Measurement and assessment in teaching. $9^{\text {th }}$ ed. Upper Saddle River, NJ: Merrill-Prentice Hall.

Luyegu, E. A. (2009). Students' perceptions of assessment and the electronic portfolio project in the college of education. Unpublished $\mathrm{PhD}$ Thesis. University of South Alabama, Mobile, AL.

Masole, T. M., \& Howie, S. (2013). Exploring teachers' assessment practices of performance tasks in agriculture and factors influencing their choice. Journal of Agricultural \& Food Information, 14(3), 209-224.

McMillan, J., Myran, S., \& Workman, D. (2002). Elementary teachers' classroom assessment and grading practices. Journal of Educational Research, 95(4), 203-213.

McMillan, J. H. (2001). Essential assessment concepts for teachers and administrators. Thousand Oaks, CA: Corwin Press.

Mehrens, W. A., \& Lehmann, I. J. (1991). Measurement and evaluation in education and psychology. $3^{\text {rd }}$ ed. New York, NY: Holt, Rinehart and Winston.

Messineo, M., Gaither, G., Bott, J., \& Ritchey, K. (2007). Inexperienced versus experienced students' expectations for active learning in large classes'. College Teaching, 55(3), 125-133.

Miller, M. D., Linn, R. L., \& Gronlund, N. E. (2009). Measurement and assessment in teaching $\left(10^{\text {th }}\right.$ ed.). New Jersey: Pearson Education Ltd.

Nega, M. (2012). Quality and quality assurance in Ethiopian higher education: critical issues and practical implications. Unpublished $\mathrm{PhD}$ Thesis. University of Twente, Enscheda, the Netherlands. Ipskamp Drukkers.

Nenty, H. J., Adedoyin, O. O., Odili, J. N., \& Major, T. E. (2007). Primary teacher's perceptions of classroom assessment practices as means of providing quality 
primary/basic education by Botswana and Nigeria. Educational Research and Review, 2(4), 074-081.

Norton, L., Norton, B., \& Sadler, I. (2012). Assessment, marking and feedback: understanding the lecturers' perspective. Practitioner Research in Higher Education, 6(2), 3-24.

Oladele, I. O. (2011). Knowledge and utilization of authentic assessment techniques by lecturers in Botswana college of Agriculture. NACTA Journal, 55(1), 63-67.

Race, P., Brown, S., \& Smith, B. (2005). 500 Tips on Assessment. $2^{\text {nd }}$ ed. London and New York. Routledge Falmer.

Samuelowicz, K., \& Bain, J. (2002). Identifying academics' orientations to assessment practice. Higher Education, 43(2), 173-201.

Smimou, K., \& Dahl, D. W. (2012). On the relationship between students' perceptions of teaching quality, methods of assessment, and satisfaction. Journal of Education for Business, 87(1), 22-35.

Stassen, M. L. A. (2001). Program based review and assessment: Tools and techniques for program improvement. Amherst, MA: University of Massachusetts.

Tadesse, A. (2009). The status, gaps, and challenges of implementing continuous assessment: the case of second cycle primary schools in Debre Markos Town. Unpublished MA Thesis. Addis Ababa University, Addis Aba. 